УДК 378:37.013.3

\title{
ПІДХОДИ ДО ВДОСКОНАЛЕННЯ ЗМІСТУ ВИКЛАДАННЯ КУРСУ «ІСТОРІЯ УКРАЇНИ» У ВИЩИХ НАВЧАЛЬНИХ ЗАКЛАДАХ ВІДПОВІДНО ДО ВИМОГ ДОСЛІДНИЦЬКОГО НАВЧАННЯ
}

\section{Тамара Баклашова}

старший викладач кафедри культурології, естетики та історії

Донбаський державний педагогічний університет, м. Слов'янськ, Україна

ORCID ID E-3615-2018

cult.ddpu@gmail.com

\author{
Володимир Проскунін \\ кандидат педагогічних наук, доцент, \\ проректор з науково-педагогічної роботи \\ і соціально-економічного розвитку, \\ ДВНЗ «Донбаський державний педагогічний університет», \\ м. Слов’янськ, Україна
}

Анотація. В статті досліджуються можливості застосування новітніх методологічних підходів до оновлення змісту курсу історії у вищій школі. Метою оновлення визначено досягнення відповідності між принципами дослідницького навчання та завданнями історичної освіти. Простежено можливості застосування кожного з методологічних підходів на певному етапі дослідницького навчання. Виявлено, що найбільш перспективними є принципи антропологізації, сполучення макроісторії з мікроісторією, історії ідей, історії повсякденності.

Ключові слова: зміст освіти; дослідницьке навчання; курс історії України; вища освіта.

Постановка проблеми в загальному вигляді. Оновлення змісту історичної освіти є актуальним завданням сучасної науки та педагогічної практики. Зміна парадигми історичного знання відповідає потребам розвитку суспільства, відповідно змінюється і змістовне наповнення навчальних дисциплін історичного циклу. Сучасними зарубіжними та вітчизняними науковцями запропоновано декілька принципових методологічних підходів до зміни парадигми історичних досліджень. Найбільш перспективними серед них $\epsilon$ антропологізація історичного знання, сполучення мікроісторії із макроісторією, історія ідей. Ці підходи рівною мірою можуть бути застосовані і до розробки змістовного наповнення курсів історії у вищому навчальному закладі, забезпечуючи їхнє оновлення та відповідність сучасним вимогам. Водночас застосування нових методологічних підходів не $є$ самоціллю, а виступає частиною загального процесу розвитку науки. У сучасному вищому навчальному закладі має відбуватися не лише засвоєння студентами певної суми знань i навичок, а всебічний розвиток особистості та підготовка фахівця, який опанував

() ДВНЗ «Донбаський державний педагогічний університет» 
Підходи до вдосконалення змісту викладання курсу «Історія України» у вищих навчальних закладах відповідно до вимог дослідницького навчання

ключові компетентності своєї професії на найвищому рівні. Провідною серед цих компетентностей є здатність до самостійного наукового дослідження та продукування нового знання. Цій меті має бути підкорений увесь процес навчання у виші, і кожна з навчальних дисциплін має власний потенціал у вирішенні цього завдання. Тому більшість вищих навчальних закладів сьогодні організовують навчальний процес за вимогами дослідницького навчання. Отже, перед фахівцями вищої школи постає проблема оновлення змісту навчальних дисциплін відповідно до потреб сучасного суспільства. Особливо актуальним це завдання є для історії України, яка виконує, зокрема, й ідеологічну функцію.

Аналіз останній досліджень і публікацій. Проблема дослідницького навчання як найбільш перспективної парадигми в умовах сучасної вищої освіти неодноразово знаходила висвітлення в працях вітчизняних науковців, зокрема Р. Вернидуба, О. Крушельницької， Г. Лиходєєвої， Н. Мирончук， П. Мороз, А. Степанюк, В. Шейко та ін. Цими та іншими дослідниками проаналізовано як теоретичні, так і методичні принципи дослідницького навчання та обгрунтовано перспективи його впровадження. Необхідність оновлення змісту вищої освіти, зокрема в історичній галузі, також неодноразово обговорювалась у науковому середовищі, важливі пропозиції 3 цього приводу було сформульовано В. Вашкевичем, I. Гирич, П. Горохівським, В. Кравцем та ін. Однак конкретні вимоги, які постають перед змістом історичної освіти в умовах дослідницького навчання, а також перспективи, які розкриває історичне знання для реалізації принципів дослідницького навчання, досі залишались поза увагою науковців.

Формулювання цілей статті. Метою статті є проаналізувати специфіку історичної освіти з погляду запровадження принципів дослідницького навчання та запропонувати конкретні напрями оновлення змісту викладання історії в межах сучасних методологічних підходів.

Методи дослідження. $\mathrm{y}$ дослідженні застосовувались методи теоретичного аналізу і синтезу для з'ясування основоположних принципів дослідницького навчання; концептуально-порівняльного аналізу для вивчення провідних методологічних напрямів сучасної історичної науки та можливостей їхнього застосування 3 метою оновлення змісту викладання історії у вищій школі.

Результати дослідження. Основоположні принципи дослідницького навчання у виші на сьогодні $є$ достатньо грунтовно розробленими і мають кінцевою метою формування в студентів специфічної компетентності, завдяки якій майбутній фахівець виявляється здатним до самостійної дослідницької діяльності (Горохівський, 2016). До складу цієї компетентності входять 
Підходи до вдосконалення змісту викладання курсу «Історія України» у вищих навчальних закладах відповідно до вимог дослідницького навчання

систематизовані знання, уміння i навички, світоглядні переконання, психологічні риси особистості, мотиваційні орієнтації, які в цілокупності виявляються як функціональна готовність фахівця до творчого пошукового вирішення пізнавальних та практичних завдань.

Цю систему можна поділити на підсистеми, кожна 3 яких має важливе значення. Це насамперед мотиваційно-ціннісна підсистема, яка передбачає спрямованість особистості на активне дослідження та перетворення довколишнього світу, сформований науковий світогляд, усвідомлення нового знання як цінності, дотримання академічної доброчесності тощо. На другому місці стоїть операційно-організаційна підсистема, яка включає володіння конкретними дослідницькими вміннями, розумовими прийомами і операціями дослідницької діяльності, зокрема навички аналізу й синтезу, абстрагування й узагальнення, висунення гіпотези, планування й регуляції власних дій, практичні навички пошуку й обробки інформації та організації експерименту. Третє місце займає комунікативна підсистема, яка відповідає за здатність до співробітництва в процесі дослідницької діяльності, уміння належним чином висловити та обгрунтувати свої висновки, захистити власні судження в науковій дискусії (Вашкевич, 2005).

Весь процес навчання у вищій школі в сучасних умовах має бути організований як дослідницький процес, коли студент не отримує знання в готовому вигляді, а здобуває його під час самостійної навчально-дослідницької діяльності. Вимогам такого навчання мають відповідати i змістовна, i організаційна складові навчально-виховного процесу. Кожна 3 дисциплін, які вивчаються у вищому навчальному закладі, своєю мірою виконує завдання формування дослідницької компетентності студента, проте кожна 3 дисциплін має власну специфіку в змісті навчання, зокрема й курс вітчизняної історії.

Необхідність оновлення змісту історичної освіти у світовій педагогічній практиці обговорюється вже 3 80-х років ХX ст., особливо актуальним це питання стало на початку XXI ст. Сучасні виклики, що стоять перед людством, зокрема проблема глобалізації, активні міграції населення, мультикультурність сучасних суспільств, демократизація гуманітарної політики розвинутих держав світу, швидкість поширення та загальнодоступність інформації, поява нових форм суспільних практик у зв’язку з відкриттям новітніх інформаційних технологій - усе це передбачає докорінне переосмислення способів історіописання та парадигм розуміння історичного процесу (Мороз, 2012). Для України додається ще й необхідність нового осмислення національної історії в умовах незалежної держави. Серед перспективних методологічних підходів, які 
Підходи до вдосконалення змісту викладання курсу «Історія України» у вищих навчальних закладах відповідно до вимог дослідницького навчання

на сьогодні напрацьовані вітчизняними та зарубіжними істориками, найчастіше застосовуються такі (Гирич, 2009):

1. Антропологізація історії, тобто наближення історичного знання до конкретної особистості з іï проблемами, здобутками, життєвим середовищем тощо. Історія з погляду прибічників цього підходу повинна розглядатися не як історія держав, націй або географічних регіонів, а як історія людей в усьому різноманітті їхнього буття.

2. Сполучення мікроісторії з макроісторією. Цей методологічний підхід є логічним продовженням попереднього і передбачає висвітлення історичного процесу як співіснування локальних людських спільнот (етнічних груп, територіальних громад, релігійних об'єднань), пов’язаних між собою особистісними зв'язками. Завдання узагальнення історичних подій виконує погляд на історію цих спільнот на рівні найбільших об’єктивно існуючих людських спільнот - цивілізацій.

3. Історія ідей, або розгляд історичного процесу як зміни світоглядних парадигм, рівнів розвитку пізнання світу, філософських концепцій тощо.

4. Історія повсякденності, або заглиблення в конкретні життєві умови всіх представників певного суспільства на певному етапі його розвитку.

На практиці ці методологічні підходи найчастіше поєднуються між собою i не $\epsilon$ взаємовиключними, їхнє сполучення забезпечує найголовніший принцип дослідження, який не викликає жодних заперечень у сучасних науковців - у центрі історичного знання має бути особистість (Горохівський, 2016). Саме така парадигма відповідає сучасним завданням вищої освіти, тому перспективність оновлення змісту вищої історичної освіти відповідно до цих принципів не викликає сумнівів. Розглянемо конкретні цілі такого оновлення та спробуємо спрогнозувати його результати в межах дослідницького навчання.

Дослідницьке навчання передбачає такий спосіб організації навчальновиховного процесу, за якого кожне навчальне завдання має передбачати реалізацію основних етапів наукового дослідження, а саме: послідовну постановку питання та формулювання дослідницької проблеми, збір та аналіз інформації, необхідної для вирішення цієї проблеми, їі систематизацію та узагальнення, висування гіпотези та їі перевірку, отримання нового знання та його обгрунтування згідно з науковою методологією. На кожному з цих етапів формуються та розвиваються необхідні дослідницькі компетентності, які й забезпечують у результаті готовність майбутнього фахівця до самостійної дослідницької діяльності (Вернидуб, 2012).

Отже, перший етап дослідницької роботи передбачає усвідомлення 
Підходи до вдосконалення змісту викладання курсу «Історія України» у вищих навчальних закладах відповідно до вимог дослідницького навчання

проблеми й постановку дослідницького завдання, формулювання мети дослідження. У процесі вивчення історії дослідницька проблема постає в двох варіантах: по-перше, як наукове історичне питання, тобто необхідність встановити причини або наслідки тих чи тих історичних подій, ступінь участі та роль у цих подіях певних діячів чи груп; по-друге, як проблема оцінки певних подій з погляду їхнього впливу на сьогодення. Саме другий варіант є найбільш перспективним 3 погляду дослідницького навчання та оновлення змісту освіти. Власне, оволодіння певною інформацією про історичні події не можна сьогодні вважати актуальним завданням курсу історії у вищій школі, адже необхідний мінімум знань учні засвоюють у процесі здобуття середньої освіти. Вища школа має не стільки розширити або поглибити ці знання, скільки надати студенту можливість розвинути власну особистість у процесі навчання.

Отже, зміст історичної освіти необхідно вдосконалювати в напрямку збільшення можливостей для студентів формулювати оціночні судження про історичні події. При цьому в контексті зазначених вище методологічних підходів можна запропонувати студентам такі проблеми, які б максимально наближували історичну подію до їхнього власного розуміння, наприклад, розглядати ї 3 погляду молодої людини певного періоду, з погляду регіональної або етнічної спільноти, до якої належить студент, у контексті панівного на той час світогляду порівняно 3 сучасним тощо. Такий кут зору дасть можливість водночас активізувати пізнавальну діяльність студентів, збільшити мотивацію до оволодіння знанням, але найголовніше, сприятиме формуванню в них важливих для успішної соціалізації якостей особистості (Кравець, 2012).

Успішне оволодіння науковим інструментарієм та організаційними дослідницькими компетентностями на цьому етапі навчального процесу має забезпечуватися водночас демонстрацією студентам різноманітних поглядів на проблему відомих вітчизняних і зарубіжних науковців та стимулюванням їхньої самостійної творчості в постановці питання. У змісті викладання історії України 3 цією метою варто забезпечити наявність різноманітних, зокрема контроверсійних поглядів на проблему, аналізуючи які студенти мають побачити весь спектр думок на питання, а також увести в зміст навчання матеріал особистісного характеру, якомога яскравіше подати певну історичну подію, урахувати місцеву специфіку з метою активізувати дослідницьку активність студентів.

Комунікативна підсистема дослідницької компетентності на етапі формулювання наукової проблеми виступає як здатність до розуміння сутності повідомлення, на основі якого формулюється дослідницька проблема, а також як

() ДВНЗ «Донбаський державний педагогічний університет» 
Підходи до вдосконалення змісту викладання курсу «Історія України» у вищих навчальних закладах відповідно до вимог дослідницького навчання

здатність до чіткого формулювання сутності виявленого питання. 3 метою розвитку та вдосконалення цієї групи вмінь у зміст історичної освіти варто вводити якомога більшу кількість різноманітних за формою та цільовим призначенням історичних джерел, аналіз яких забезпечить студентам навичку розуміння змісту повідомлення (Шейко, 2003).

Наступний етап дослідницького навчання передбачає пошук студентами інформації для вирішення дослідницької проблеми, перевірку, аналіз та систематизацію цієї інформації. Історія як навчальна дисципліна може забезпечити на цьому етапі значно більше можливостей, ніж інші курси, що викладаються у вищій школі. Причина цього в тому, що історія як наука оперує найрізноманітнішими джерелами, комплекс яких охоплює всю життєдіяльність людини. При цьому кожний із видів історичних джерел потребує власної методики для перевірки та аналізу, а їхнє адекватне використання передбачає оволодіння цілим комплексом суміжних знань. В умовах дослідницького навчання варто не нехтувати цим етапом роботи і не пропонувати студентам уже готову інформацію, коли історичні джерела є лише ілюстрацією для твердження підручника або викладача. Навпаки, у зміст освіти варто ввести якомога більшу кількість видів джерел відповідно до цілей конкретного заняття.

Перераховані вище методологічні підходи до оновлення змісту історичної освіти в застосуванні до завдань етапу пошуку та обробки інформації в умовах дослідницького навчання дають змогу запропонувати деякі конкретні поради щодо змістовного наповнення курсу. Зокрема, варто забезпечити під час вивчення кожної теми, у якій передбачається вирішення проблемного питання, опрацювання студентами, окрім важливих історичних документів, також і матеріалів особистісного походження, джерел, що дають змогу зрозуміти рівень життя певної людської спільноти, джерел, які демонструють множинність таких спільнот для кожного історичного періоду, відмінність між різними регіонами однісіі країни або між різними верствами суспільства, джерел, які репрезентують панівні на той час у суспільстві ідеї та різні способи їхньої вербалізації. Здійснювати відбір таких джерел варто за певною ієрархічною схемою, де на найнижчому щаблі будуть свідчення індивідуального буття людини, далі інформація про окремі спільноти, i, нарешті, про все суспільство. Не слід забувати також і про опанування студентами науковим інструментарієм інформаційного пошуку: серед необхідних для вирішення проблеми джерел варто передбачити їхні різні види та різні шляхи пошуку й аналізу (Уйсімбаєва, 2006).

Наступний етап дослідницького навчання своїм головним завданням має

Професіоналізм педагога: теоретичні й методичні аспекти. - Вип. 11. - Слов’янськ, 2019. 
Підходи до вдосконалення змісту викладання курсу «Історія України» у вищих навчальних закладах відповідно до вимог дослідницького навчання

формулювання гіпотези як відповіді на дослідницьку проблему. Цей етап найбільше сприяє формуванню в студентів креативної складової дослідницької компетентності, здатності продукувати нові знання та смисли. Серед підсистем дослідницької компетентності на цьому етапі найбільше розвиваються мотиваційно-ціннісна та комунікативна. Природна для молодої людини мотивація до опанування довколишнього світу, його перетворення, утвердження власної індивідуальності на цьому етапі виступають могутнім стимулом до навчання в межах дослідницького організаційного підходу. Також важливим завданням $є$ розвинути й удосконалити вміння обгрунтувати власну думку, чітко й логічно сформулювати інформаційне повідомлення та донести його до аудиторії.

Плануючи цей етап навчання, необхідно передбачити такий напрямок удосконалення змісту викладання курсу історії, який би найкраще забезпечував саме особистісну мотивацію та можливості для утвердження власної особистості студента. Серед методологічних підходів, запропонованих сучасною історичною наукою, найкраще цим вимогам відповідає підхід антропологізації. Ураховуючи психологічні особливості людини молодого віку, варто надати студентам якомога більше можливостей для висловлення власної думки, але сполучити ці можливості із вивченням діяльності видатних особистостей періоду, що вивчається. Опановуючи знання про роль видатних особистостей в історії, студенти здійснюють ментальну проєкцію їхньої діяльності на власні здобутки. Тому варто забезпечити студентів всебічною інформацією про юнацькі роки видатних діячів національної історії, про їхній шлях до вершин політичної або громадської кар'єри, не варто уникати інформації про помилки і прорахунки видатних історичних персонажів, це сприятиме розвитку почуття відповідальності за власні дії. Звичайно, креативності навчити дуже важко, але стимулювати бажання проявляти індивідуальні здібності оновлення курсу історії у вказаному напрямі, безумовно, варто.

Ще одним перспективним методологічним підходом до оновлення змісту викладання історії у вищому навчальному закладі є історія ідей (Мороз, 2012). Формулювання наукової гіпотези як відповіді на проблемне питання передбачає використання певної наукової методології. Усвідомлення цього, своєрідна методологічна чистота продукованого нового знання є однією з першочергових навичок, які необхідно сформувати в майбутнього спеціаліста. 3 цією метою варто запропонувати сформулювати декілька відповідей на поставлену проблему, виходячи із принципово відмінних політичних або релігійних світоглядів чи національних інтересів. Наприклад, як оцінювали ті або ті події 
Підходи до вдосконалення змісту викладання курсу «Історія України» у вищих навчальних закладах відповідно до вимог дослідницького навчання

католики, православні та протестанти, чим відрізнялось сприйняття одних і тих самих процесів українцями та поляками, у чому головний зміст протистояння між політичними супротивниками в умовах громадянських конфліктів. Для всебічного аналізу варто запропонувати різноманітні за змістом історичні джерела. Усвідомлення впливу на події тієї або тієї світоглядної парадигми дасть можливість розширити здатність майбутнього спеціаліста до успішної адаптації в суспільстві.

Завершальним етапом дослідницького навчання $\epsilon$ захист отриманих результатів. Цей етап передбачає насамперед розвиток комунікативної підсистеми дослідницької компетентності, тобто здатності донести свою думку, методологічно грамотно ii аргументувати, психологічну готовність до відстоювання власних поглядів за умови поваги до думки опонента (Крушельницька, 2003). На цьому етапі змістовне оновлення курсу історії повинне відбуватись в контексті методологічного підходу, який передбачає сполучення мікроісторії з макроісторією. Усвідомлення свого входження до тканини світового історичного процесу, впливу на локальні процеси процесів глобальних розширить можливості студентів до взаємопорозуміння та поняття про множинність думок, розвиток навички розуміння відмінності між об'єктивним і суб'єктивним у науковому знанні. У змісті історичної науки закладено вагомий ресурс для розвитку вищевказаних умінь, бо історична інформація сполучає конкретність фактографічного матеріалу з різноманітністю його наукової інтерпретації, а також методологічний принцип хронологічності, який забезпечує розвиток системності мислення.

Усі вищеназвані етапи навчального процесу, організованого в умовах дослідницького навчання, мають виступати водночас організаційним принципом планування кожного навчального заняття і кожної з форм навчальної роботи зокрема, а також єдиним принципом організації всього навчального курсу загалом. Реалізація цієї вимоги можлива за умови дотримання єдності методологічних підходів до змісту навчання, коли кожна 3 тем, які розглядаються в межах курсу, $\epsilon$ водночас самостійним завершеним дослідницьким завданням i частиною великого дослідження. Крім того, необхідно дотримуватись вимоги активізації міжпредметних зв’язків, бо в умовах сучасної вищої школи дослідницьке навчання є ключовою вимогою якісного навчального процесу.

Висновки 3 дослідження і перспективи подальших розвідок у цьому напрямі. Проведене дослідження свідчить, що оновлення змісту викладання курсу історії у вищій школі не лише здатне забезпечити кращі результати

Професіоналізм педагога: теоретичні й методичні аспекти. - Вип. 11. - Слов’янськ, 2019. 
Підходи до вдосконалення змісту викладання курсу «Історія України» у вищих навчальних закладах відповідно до вимог дослідницького навчання

засвоєння навчального матеріалу, але й за умови дотримання певних методологічних принципів може сприяти розвитку дослідницької компетентності майбутніх спеціалістів. Ці методологічні принципи загалом співпадають із тими напрямками методологічного оновлення історичного знання, які пропонуються сьогодні провідними науковцями. Це такі напрямки, як антропологізація історичного знання, сполучення в об’єкті дослідження макроісторії із мікроісторією, дослідження історії суспільства як історії панівних ідей, вивчення історії як історії повсякденності. Кожний із цих підходів, будучи застосованим на певному етапі дослідницького навчання, забезпечує широкі можливості для розвитку специфічної компетентності, завдяки якій майбутній фахівець виявляється здатним до самостійної дослідницької діяльності. До складу цієї компетентності входять систематизовані знання, уміння і навички, світоглядні переконання, психологічні риси особистості, мотиваційні орієнтації, які в цілокупності виявляються як функціональна готовність фахівця до творчого пошукового вирішення пізнавальних та практичних завдань. Серед конкретних пропозицій щодо оновлення змісту навчального курсу історії, які випливають із застосування вказаних методологічних підходів, варто виділити розширення навчального матеріалу, який передбачає самостійні оціночні судження студентів, збільшення кількості та урізноманітнення змісту історичних джерел, які пропонуються для опрацювання, розширення інформації щодо повсякденного життя людини в певні історичні епохи, докладне ознайомлення студентів з альтернативними поглядами на історичний процес.

Подальших досліджень потребує з’ясування перспективи оновлення змістовного наповнення курсу історії у вищому навчальному закладі в контексті розширення міжпредметних зв'язків і можливостей варіативного змістовного наповнення курсу для різних спеціальностей.

\section{СПИСОК ВИКОРИСТАНИХ ДЖЕРЕЛ}

1. Вашкевич, В. (2005) Методика викладання історії: необхідність оновлення. Політичний менеджмент, 6, 114-120.

2. Вернидуб, Р. (2012) Формування дослідницької компетентності студентівбакалаврів педагогічних університетів. Рідна школа, 6, 58-62.

3. Гирич, I. (2009) Українська історична освіта на початку XXI століття. Iсторія в школах України, 5, 2-4.

4. Горохівський, П.І. (2016) Методика викладання історичних дисичиллін у вищзій школі. Умань, Україна.

5. Кравець, В. (2012) Проблеми модернізації вищої освіти в Україні в умовах глобалізації. Украӥна-Свропа-Світ, 10, 15-23.

6. Крушельницька, О.В. (2003) Методологія $і$ організащчія наукових досліджень студентів. Київ, Україна: Кондор.

7. Лиходєєва, Г. В. (2007) Навчально-дослідницькі уміння та дослідницька діяльність 
Підходи до вдосконалення змісту викладання курсу «Історія України» у вищих навчальних закладах відповідно до вимог дослідницького навчання

учнів у психолого-педагогічній літературі. Дидактика математики: проблеми та дослідження, 27, 89-94.

8. Мороз, П.В. (2012) Дослідницька діяльність учнів в прочесі навчання історії України. Київ, Україна: Педагогічна думка.

9. Степанюк, А.В. і Москалюк, Н.В. (2010) Розвиток дослідницьких умінь студентів як складова професійної підготовки майбутніх учителів природничого профілю. Професійна освіта, 2, 33-38.

10. Уйсімбаєва, Н. (2006) Науково-дослідницька діяльність як чинник зростання професійної компетентності. Рідна школа, 4, 3-6.

11. Шейко, В.М. (2003) Організація та методика науково-дослідницької діяльності. Київ, Україна: Знання-Пресс.

\title{
APPROACHES TO IMPROVING THE CONTENT OF THE HISTORY OF UKRAINE IN HIGHER EDUCATION IN ACCORDANCE WITH THE REQUIREMENTS OF RESEARCH TRAINING
}

\author{
Tamara Baklashova \\ Senior Lecturer of \\ the Department of Culture Studies, Ethics and Aesthetics \\ SHEI "Donbas State Pedagogical University" \\ Sloviansk, Ukraine \\ Volodymyr Proskunin \\ Candidate of Pedagogical Sciences, Associate Professor, \\ Vice-rector for scientific and pedagogical work \\ and socioeconomic development, \\ SHEI "Donbas State Pedagogical University" \\ Sloviansk, Ukraine
}

\begin{abstract}
The task of updating the content of historical education stems from the demands of social development and the emergence of fundamentally new methodological approaches to historical research. The most promising areas for updating the historical research are called by modern scholars the anthropologization of historical knowledge, the combination of micro history with macro history, and the history of ideas. Modern higher education aims at the comprehensive development of the student's personality and the formation of his/her capacity for independent scientific research. This objective can be achieved within the organization of the educational process based on the principles of research training. In accordance with these principles, the content of the disciplines, including the "Ukrainian History", should be updated.

The issue of research training as the most promising paradigm in the context of modern higher education has repeatedly been highlighted in the writings of domestic scientists, in particular: R. Vernidub, O. Krushelnytska, G. Lykhodieieva, N. Myronchuk, P. Moroz, A. Stepaniuk, V. Sheiko, V. Vashkevych, I. Hyrych, P. Horokhivskyi, and others.

The purpose of this article is to analyze the specifics of historical education from the point of view of introducing principles of research training and to propose specific directions for updating the content of history teaching within current methodological approaches.

Updating the content of a history course at a tertiary institution, according to the latest methodological principles, may contribute to the development of research competence of future
\end{abstract}

Професіоналізм педагога: теоретичні й методичні аспекти. - Вип. 11. - Слов’янськ, 2019. 


\section{Т. БАКЛАШОВА, В. ПРОСКУНІН}

Підходи до вдосконалення змісту викладання курсу «Історія України» у вищих навчальних закладах відповідно до вимог дослідницького навчання

specialists. They are such principles as the anthropologization of historical knowledge, the combination of macro history with micro history in the object of research, the study of the history of society as a history of dominant ideas, and the study of history as a history of everyday life. As the result of such an update we get the development of research competence as a system of knowledge, worldview skills, psychological personality traits, motivational orientations, which in a professional activity are proved to be a functional readiness of a specialist for creative search of solving cognitive and practical tasks.

New methodological approaches to updating the content of historical education, applied at a particular stage of research teaching, provide ample opportunity for students to be able to undertake independent research activities. The best results are the extension of the educational material, which ensures independent assessment judgments of students, increase of the number and content of historical sources that are offered for processing and detailed introduction of alternative perspectives of the historical process to students.

Key words: content of education; research training; course of Ukrainian history; higher education.

\section{REFERENCES}

1. Vashkevych, V. (2005) Methodology of teaching history: the need for updating. Politychnyi menedzhment, 6, 114-120.

2. Vernydub, R. (2012) Formation of research competence of undergraduate students of pedagogical universities. Ridna shkola, 6, 58-62.

3. Hyrych, I. (2009) Ukrainian historical education at the beginning of the 21st century. Istoriia $v$ shkolakh Ukrainy, 5, 2-4.

4. Horokhivskyi, P.I. (2016) Methods of teaching historical disciplines in high school. Uman, Ukraine.

5. Kravets, V. (2012) Problems of modernization of higher education in Ukraine in the conditions of globalization. Ukraina-Yevropa-Svit, 10, 15-23.

6. Krushelnytska, O.V. (2003) Methodology and organization of student research. Kyiv, Ukraine: Kondor.

7. Lykhodieieva, H. V. (2007) Educational and research skills and research activity of students in psychological and pedagogical literature. Dydaktyka matematyky: problemy ta doslidzhennia, 27, 89-94.

8. Moroz, P.V. (2012) Research activity of students in the process of teaching history of Ukraine. Kyiv, Ukraine: Pedahohichna dumka.

9. Stepaniuk, A.V. \& Moskaliuk, N.V. (2010) Development of students' research skills as a part of professional training of future teachers of natural profile. Profesiina osvita, 2, 33-38.

10. Uisimbaieva, N. (2006) Research as a factor in the growth of professional competence. Ridna shkola, 4, 3-6.

11. Sheiko, V.M. (2003) Organization and methodology of research activities. Kyiv, Ukraina: Znannia-Press.

Матеріали надійшли до редакції 26.09.2019 р. 